\title{
Effects of Music-Based Intervention on English Proficiency among Primary School Pupils in Selangor
}

\author{
Lum Li Yuen \\ Department of Music, Faculty of Human Ecology, Universiti Putra Malaysia, Selangor, Malaysia \\ Email: liyuen1808@gmail.com
}

How to cite this paper: Yuen, L. L. (2022). Effects of Music-Based Intervention on English Proficiency among Primary School Pupils in Selangor. Open Journal of Social Sciences, 10, 99-110.

https://doi.org/10.4236/jss.2022.102006

Received: January 4, 2022

Accepted: February 12, 2022

Published: February 15, 2022

Copyright $\odot 2022$ by author(s) and Scientific Research Publishing Inc. This work is licensed under the Creative Commons Attribution International License (CC BY 4.0).

http://creativecommons.org/licenses/by/4.0/

Open Access

\begin{abstract}
Based on existing research, the current status of English literacy skills among low performing pupils in national primary schools is a serious cause for concern. Early intervention to tackle this problem is critical to help children catch up with the expected educational standards which include speaking, listening, reading, and writing skills at each level of study. Therefore, this study set out to investigate the effects of music-based intervention on English proficiency among primary school pupils by using improvised teaching materials from the CEFR Year 3 syllabus as material which ought to be able to satisfy students' require and, both present future needs and to examine the participation level of pupils from the music-based intervention. This research employed a quantitative approach with a pre-test-post-test quasi-experimental design. A total of forty Year Three Students $(N=40$ pupils, divided into 2 groups; quasi-experimental and control group) participated in the study. Data was collected using speaking assessments and observation checklist. The findings of the study showed that there was a significant difference between the quasi-experimental groups following music-based intervention with improvised materials. Students who had gone the through music-based intervention using improvised materials had showed improvement not only in the content and vocabulary in the materials, but also their speaking skills, especially their pronunciation and fluency. Results also illustrated that the inclusion of a music-based intervention and improvised materials in English class appears to have motivated the pupils to participate actively in the class discussion.
\end{abstract}

\section{Keywords}

Improvised Teaching Materials, Low Performing Pupils, Music-Based Intervention, Speaking Skills 


\section{Introduction}

Being able to read, write and communicate in English is important because it is an international language and being used world-wide. Also, language proficiency is an important influencing factor of interactions among students from the different nationalities (Krishnan \& Yunus, 2019). Due to its importance, Ministry of Education Malaysia has taken different initiatives to ensure that English language is mastered by all and currently the use of CEFR syllabus and assessment. The current status of English literacy skills among low performing pupils in national primary schools is a serious cause for concern. According to a local study by Azman, Lie and Musa (2012) who reviewed the factors that contribute to low or restricted English acquirement skills among Malaysian learners such as influences of English are strong among students resulting in English language teaching be difficult. Teachers also face challenges in creating the environment for teaching and learning English to meet current needs. In essence, the overall situation is strongly indicative that more help and support need to be extended to supplement current English teaching methods to improve English proficiency skills amongst Malaysian school children.

As we know, music surrounds us every day and it brings joy to us as music has been a part of people's lives. According to Anne (2016), the level to which the capacity and sensitivity to music are programmed in the human brain or are by-products of other established order and tendencies in the culture of music. Without a doubt, music plays a fully central and basic role, and it seems that the desire for music is deeply rooted in human nature. Therefore, the use of music in teaching and learning will be able to create an environment that is fun for students to learn. Moreover, music can be used in a variety of ways, like in the classroom to promote English literacy (Bokiev et al., 2018). Music may be used to train all skills, including speaking, listening, reading, and writing, in the same manner that it can be used to train language areas, beginning with grammatical structures and vocabulary, and finishing with fluency, stress, rhythm, and pronunciation (Rosová, 2007). Music also aids in the development of cultural awareness in pupils while also providing valuable learning opportunities. As a result, proper music selection can make literacy class more enjoyable and less rigid. The selection, on the other hand, should be compatible with classroom activities that cover a variety of components of English language acquisition. Singing, movement with songs, music games, charade, and other music-integrated classroom activities are examples. The reason why we can use songs in our class is because songs act as a melioration of memory of text and may be an effective way to provoke language acquisition (Tse, 2015).

Overall, primary students in Malaysia are still struggling to acquire strong foundation of speaking skill in the target language. The application of music in classroom can be helpful to support their language development (Tegge, 2015). It can also develop their cultural awareness and help them to accept the language with ease. Music integrated teaching materials also helpful for teachers to boost 
their students' motivation and confident by making it more relatable and easier to comprehend. Challenges such as anxiety, shyness and lack of language practice can be lessened using music integrated materials in the classroom (Bokiev et al., 2018; Degrave, 2019; Matei \& Ginsborg, 2017). To maximize the classroom time that teachers have, they should apply variety of method to ensure the students can get the most out of it. This study focuses on how music integrated classroom can help to improve the low-performing pupils writing and reading skill; and build up their self-assurance in order to communicate with peers and adults appropriately using English language.

\section{Music-based intervention}

Music-based therapies are utilized to address a variety of issues that people face throughout their lives, from infants to the elderly (Burns et.al, 2010). Singing, listening to music, and playing an instrument are all examples of music-based interventions. Formal music-based intervention, according to Altenmüller et al. (2017), can be defined as active intervention (e.g., making music, singing, playing an instrument, or musical improvisation) or receptive intervention (e.g., music listening) that is overseen by a credentialed music therapist (panel). Music-based therapies, he continued, may influence different functions in these patient groups, such as communication, motor performance, and cognition.

Likewise, in this study music-based intervention refers to the use of the improvised "Smart Friend song" by localizing the content of the song in speaking English classroom. During this intervention, the English teacher will use the improvised Year 3 song and localized materials like pictures and the content of the song to engage with students and encourage students to participate more during the speaking lessons. According to Israel (2013) music-based intervention requires teacher and students to learn using the music in acquiring the vocabulary, phonetics and semantics.

\section{Speaking skills}

Speaking skills include the fluency, accuracy and interaction in speaking. According to the criteria of level A1 given by CEFR (Ministry of Education, MoE, 2018), fluency is the ability to articulate less familiar words, very short, isolated, mainly pre-packaged utterances, with much pausing to explore for expressions, and to repair communication whereas accuracy is the control of few grammatical structures as well as sentence patterns in a memorized repertoire. Interaction is the ability to communicate in a simple way however communication is entirely dependent on repetition, rephrasing and repair. In this study, fluency refers to how fast and how much a learner speaks without dysfluency markers, Accuracy is the vocabulary and sentence pattern used, pronunciation of the words. Interaction is the process of one speaker to speak out the idea and one receiver to understand the idea then gives appropriate response.

Since speaking skills are vital in language competency of primary pupils, this study focuses on the effect of a music-based intervention in developing their articulation, particularly in classroom. Speaking skill in this study refers to stu- 
dents' ability to converse meaningfully in the class, especially during class activities. Students' ability to converse meaningfully in music-based intervention class can be determined based on their speaking fluency and active participation.

\section{Research Questions}

The research question of this study is as below:

- What are the significant differences in English speaking proficiency among primary pupils before and after the music-based intervention?

- What are the significant differences in primary pupils' level of participation in English language classroom before and after the music-based intervention?

\section{Methodology}

\section{Research Design}

This research employed a quantitative approach with a pre-test-post-test quasi-experimental design. Quasi-experimental studies were used to evaluate a causal relationship between independent and dependent variables. Quasi-experiment designs use non-researcher-included variation in the main independent variable of interest. Some subjects are exposed to treatment, and others are not randomly (Gopalan et al., 2020). This research does not require a true control group but a comparison group that receives a different experimental treatment to examine the relationship between independent and dependent variables. This study will examine the impact of Music-Based and improvised teaching materials as the independent variable and speaking performance as the dependent variable. Researcher compares and contrasts the results of two intact groups: the control group that received English class lessons as usual, and the experiment group that received the "treatment" i.e. the music intervention designed to help pupils in acquiring English language skills.

In this research, randomization was not used as the researcher focused on the targeted students who had difficulties reading and communicating in English, including some introverted students who are not comfortable communicating in English. Hence, the quantitative approach and quasi-experimental approach were adopted in this research. Moreover, pre-test-post-test was conducted to evaluate the outcomes of the music intervention on pupils speaking skills and participation levels and to measure the degree of change resulting from intervention if present. Pre-test and post-test changes were compared to determine the effect of the music-based intervention on the students learning of English. To ensure similarity of baseline levels and reduce the possibility of bias, pre-test scores for both the "treatment" and control groups were compared to assure the students for both groups were at the same level. The dependent variable was measured twice: once before the "treatment" was implemented and once after it was implemented to find out to what extent a music-based intervention and improvised teaching materials help to improve pupils' speaking skills and the pupils' participation in classroom English lessons. 
This study consisted of forty (19 boys and 21 girls) low-performing pupils aged 9 years old. Both treatment group and control group would have twenty students each ( $\mathrm{N}=40$ pupils, divided into 2 groups). The number of twenty participants in a group in this study was to fit the current pupils-teacher ratio in Malaysia classroom is 1:11.61 (Ministry of Education, 2018). The school was located in a rural area with a population of around 15,000 which is situated near Bukit Puchong. They have minimal exposure towards the English language as Bahasa Malaysia is the mostly used language in their daily conversation. Many of these students had difficulties reading and communicating in English including some students who are introvert and not comfortable to communicate in English as they only scored band 1 - 2 (can read and understand simple sentences and short simple texts with visual support and full guidance) in their Pentaksiran Bilik Darjah (PBD). PBD is a classroom assessment to obtain information on student development, progress, abilities and achievement according to the descriptor given by the Kementerian Pendidikan Malaysia (KPM). The participants was chosen based on non-probability sampling, i.e., purposive sampling.

Two different instruments were used in gathering information for this study, observation checklist and speaking assessment. The research instruments in this study employed an observation checklist and speaking assessment.

\section{Intervention}

The intervention was conducted in 6 sessions for both the control and quasi-experimental group. 60 minutes were allocated for each session which sums up to 6 hours of learning session. The control group underwent the normal government syllabus which consists of non-local based textbook. The materials such as pictures, vocabulary used, flash cards, song is mainly in British content. Pupils used the materials provided by the MOE throughout the session. whereas the intervention group underwent the intervention using music-based and improvised materials by adapting the local cultures such as changing the materials used into more related/approachable to the pupils; the song tune to Malaysian famous folk song tune and create a lyrics using suitable vocabulary which is related to the pupils into the government syllabus given by the researcher. This is to help pupils who had problem comprehending new culture inserted in numerous English language lessons. This research was conducted in the classroom. Throughout the whole intervention, researcher only served as a facilitator to run the intervention. The limitation of this would be pupils might not feel comfortable and awkward during the intervention.

The comparison of both control and quasi-experimental group intervention are illustrated in Table 1.

\section{Results and Discussion}

\section{Research Question 1}

What are the significant differences in English speaking proficiency among primary pupils before and after the music-based intervention? 
Table 1. Comparison of control group and quasi-experimental group intervention.

\begin{tabular}{|c|c|c|}
\hline Steps & Control Group & Quasi-experimental group \\
\hline Pre-test/Post-test & \multicolumn{2}{|c|}{$\begin{array}{l}\text { To identify whether pupils are able to participate in discussion with peers and communicate simple } \\
\text { information intelligibly. } \\
\text { 1) A picture of a family having a picnic at the beach was shown. } \\
\text { 2) Play a game to list out the vocabulary in the picture given. } \\
\text { 3) The teacher briefly talks about the picture. } \\
\text { 4) Pupils are then divided into groups of } 5 \text {. } \\
\text { 5) Within the groups, pupils are encouraged to narrate short basic stories or events related to them } \\
\text { according to the picture. }\end{array}$} \\
\hline Lesson 1 & $\begin{array}{l}\text { Introduction of Smart Friend song } \\
\text { - } \quad \text { Introduce the original "Smart Friend" } \\
\text { song (from the CEFR Year } 3 \text { textbook). } \\
\text { - Pupils talk about the song using suitable } \\
\text { vocabulary. }\end{array}$ & $\begin{array}{l}\text { Introduction of the improvised Smart Friend song } \\
\text { (Lyrics and tune) } \\
\text { - Introduce the improvised "Smart Friend" song. } \\
\text { (The song was improvised by adding more } \\
\text { vocal into it and the researcher localized the } \\
\text { content of the song by using local names). } \\
\text { - Pupils sang it using the Chan Mali Chan song tune } \\
\text { instead of using the original tune } \\
\text { - Pupils talk about the song using suitable vocabulary. }\end{array}$ \\
\hline Lesson 2 & $\begin{array}{l}\text { Expanding adjectives } \\
\text { - Pupils list out all the adjectives they } \\
\text { found in the chant. } \\
\text { - The teacher guides pupils to form } \\
\text { longer sentences using the adjectives } \\
\text { found in the song. }\end{array}$ & $\begin{array}{l}\text { Expanding adjectives } \\
\text { - Pupils list out all the adjectives they found } \\
\text { in the improvised song. } \\
\text { - The teacher introduces a few more adjectives } \\
\text { for describing people's appearance. } \\
\text { - The teacher guides pupils to form longer sentences } \\
\text { using the adjectives found in the improvised song. }\end{array}$ \\
\hline Lesson 3 & $\begin{array}{l}\text { Describe characteristics using suitable phrases } \\
\text { - Pupils identify the character in the song and } \\
\text { describe their characteristics using suitable } \\
\text { phrases. }\end{array}$ & $\begin{array}{l}\text { Describe characteristics using suitable phrases } \\
\text { - Pupils play a miming game to review the } \\
\text { vocabulary they learned in the previous lesson } \\
\text { and the improvised "Smart Friends" song } \\
\text { - Pupils identify the character in the song and } \\
\text { describe their characteristics using suitable phrases. }\end{array}$ \\
\hline Lesson 4 & $\begin{array}{l}\text { - The teacher sticks the flashcards } \\
\text { on the board. } \\
\text { 1) In the group of five, pupils take turns to say } \\
\text { out what they can and can't do based on the } \\
\text { words given on the board. } \\
\text { 2) Other pupils are allowed to ask questions } \\
\text { to the pupil, and the teacher encourages them to } \\
\text { answer in a full sentence (Yes, I can/No, I can't) } \\
\text { Example: Can you cook? }\end{array}$ & $\begin{array}{l}\text { The teacher sticks the flashcards on the board } \\
\text { (localized materials). } \\
\text { - In the group of five, pupils take turns to say out } \\
\text { what they can and can't do based on the words } \\
\text { given on the board. } \\
\text { - Other pupils are allowed to ask questions to the } \\
\text { pupil, and the teacher encourages them to answer } \\
\text { in a full sentence (Yes, I can/No, I can't) } \\
\text { Example: Can you cook? }\end{array}$ \\
\hline Lesson 5 & $\begin{array}{l}\text { Adding adverbs help pupils expand their ability } \\
\text { to make sentences based on the normal materials } \\
\text { prepared by the Ministry of Education. } \\
\text { - Based on the adverb, pupils make } \\
\text { sentences to talk about their everyday } \\
\text { activities in group }\end{array}$ & $\begin{array}{l}\text { Adding adverbs to help pupils expand their ability to } \\
\text { make sentences based on the improvised song } \\
\text { and materials. } \\
\text { - Based on the adverb, pupils make sentences to talk } \\
\text { about their everyday activities in the group. }\end{array}$ \\
\hline
\end{tabular}


1) Pupils sit in a circle (group of five).

2) Each group is given a picture with three characters.

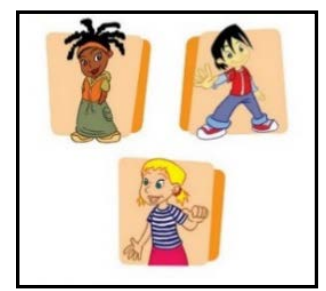

3) Pupils use the prompts in the

"Smart Friends" chant and all the information learned in the previous lesson to come out with as many sentences as they can regarding the picture.

4) Pupils talk about the three characters in groups.

5) Teacher encourages pupils to participate in the discussion
- Pupils sit in a circle (group of five).

- Each group is given a picture (localized material) with three characters.

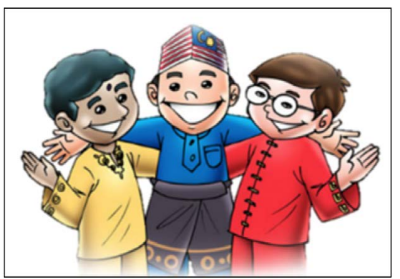

- Pupils use the prompts in the improvised "Smart Friends" song, and all the information learnt in the previous lesson to come out with as many sentences as they can regarding the picture.

- Pupils talk about the three characters in groups.

- Teacher encourages pupils to participate in the discussion.

\section{Speaking Assessment}

To investigate the students' performance, the speaking assessments were conducted before and after the implementation of music-based intervention and improvised materials.

Table 2 reveals the results of the paired sample $t$ test for the control group. Students who had attended the six lessons using the materials provided by the Malaysian Ministry of Education such as the imported English textbook; Get Smart Plus did not improve in terms of their speaking skills, $t(19)=-0.815, p=$ 0.425 . This results infers that there is no significant difference between the scores $(\mathrm{M}=-0.125, \mathrm{SD}=0.686)$ by comparing the pre-test and post-test scores. The data given shows that $p=0.425$ which indicates that $p>\mathrm{a}(\mathrm{a}=0.05)$. The $t$-value $(-0.815)$ obtained falls outside the critical region. Students from the control group had remained their speaking performances $(M=-0.125, S D=0.686)$ which their speaking scores did not show significant improvement, $t(19)=$ $0.425, p>a(a=0.05)$.

Table 3 reveals the results of the paired sample $t$-test for the quasi-experimental group. By comparing the pre-test and post-test scores, the improvement can be seen by looking at the mean different. Following six lessons of music-based intervention using the researcher created improvised music teaching materials, students had improved in their speaking skills, $t(19)=-6.807, p=0.000$. The data given shows that $p<0.001$ which indicates that $p<\mathrm{a}(\mathrm{a}=0.05)$. The $t$-value $(-6.087)$ obtained falls within the critical region. This showed that pupils who undergo the music-based intervention and the usage of localized materials in speaking lessons $(\mathrm{M}=-11.55, \mathrm{SD}=8.485)$ showed improvement in their speaking assessment, $t(19)=-6.807, p<\mathrm{a}(\mathrm{a}=0.05)$. 
Table 2. Paired sample $t$-test for control group.

\begin{tabular}{cccccc}
\hline Paired Differences & Mean Difference & Stand. Dev & $t$-value & df & Sig \\
\hline Pre-Post test & -0.125 & 0.686 & -0.815 & 19 & 0.425
\end{tabular}

Table 3. Paired sample $t$-test for Quasi-experimental group.

\begin{tabular}{cccccc}
\hline Paired Differences & Mean Difference & Stand. Dev & $t$-value & df & Sig \\
\hline Pre-post test & -11.55 & 8.485 & -6.087 & 19 & 0.000 \\
\hline
\end{tabular}

This result infers that the music-based intervention was effective in helping students to boost their English speaking skills especially the fluency of the students while having discussion in the group. These findings collectively suggest that the students from the quasi-experimental group scored higher in the post-test after implementing the music-based intervention and improvised materials in English lessons. These results further indicates that the music-based intervention and improvised music teaching materials took a short period of time (6 sessions) to assert positive changes in the speaking performance in the areas of comprehension, vocabulary, grammar, fluency and pronunciation among the 9 year old students recruited for this study.

\section{Observation Checklist}

In analyzing the interaction within the conversation between the students, the observation checklist was tabulated and compared. The observation checklist was created by the researcher and it was derived from the descriptor of the Common European Framework of Reference (CEFR) for A1 level and the Primary Content and Learning standards of KSSR which are related to speaking skills.

Table 4 illustrates the frequency scores of the observation from observer $\mathrm{C}$ that had been carried out when the students were having discussion. Overall, it is clear that student did not show a notable improvement in their interaction during the discussion. More than half (70\%) pupils were not able to use suitable words to express themselves, introduce new ideas in continuing a conversation or relate their prior knowledge in the conversation. Moreover, more than three quarter of the pupils (85\%) speak with more than 3 pauses in both pre and post-test. The observed results before and after the implementation is almost the same.

Table 5 shows the frequency scores of the observation from observer $\mathrm{C}$ that had been carried out when the students were having discussion. From the table, it is clear that student had shown a notable improvement in their interaction during the discussion as the post-test results indicate a general shift towards a higher numbers of attainment in the discussion, The results demonstrated the numbers of students able to use suitable words and pronounced it correctly, introduce new ideas and relate their previous knowledge in the conversation increased by more than $50 \%$. There's also an increase of $45 \%$ pupils who are able to speak fluently with not more than 3 pauses in the post-test in comparison to 
Table 4. Frequency distribution of the observation for Control Group.

\begin{tabular}{llrrrr}
\hline \multicolumn{2}{c}{$\begin{array}{c}\text { In relation to the speaking activities } \\
\text { during the learning process. } \\
\text { Can the pupils }\end{array}$} & \multicolumn{2}{c}{ PRE } & \multicolumn{2}{c}{ POST } \\
\cline { 2 - 6 } & YES & NO & YES & NO \\
\hline 2 & Able to use suitable words to express basic opinions? & 6 & 14 & 6 & 14 \\
3 & Able to introduce new ideas into the conversation? & 5 & 15 & 6 & 14 \\
6 & Speak fluently with not more than 3 pauses? & 3 & 17 & 2 & 18 \\
7 & Pronounce words correctly to be understood by others? & 4 & 16 & 5 & 15 \\
8 & Able to relate previous knowledge in the conversation? & 5 & 15 & 4 & 16 \\
\hline
\end{tabular}

Table 5. Frequency distribution of the observation for Quasi-experimental group.

\begin{tabular}{|c|c|c|c|c|c|}
\hline & \multirow{2}{*}{$\begin{array}{l}\text { In relation to the speaking activities } \\
\text { during the learning process. } \\
\text { Can the pupils }\end{array}$} & \multicolumn{2}{|c|}{ PRE } & \multicolumn{2}{|c|}{ POST } \\
\hline & & YES & $\mathrm{NO}$ & YES & NO \\
\hline 2 & Able to use suitable words to express basic opinions? & 5 & 13 & 12 & 8 \\
\hline 3 & Able to introduce new ideas into the conversation? & 5 & 15 & 10 & 10 \\
\hline 6 & Speak fluently with not more than 3 pauses? & 5 & 15 & 14 & 6 \\
\hline 7 & Pronounce words correctly to be understood by others? & 6 & 14 & 12 & 8 \\
\hline 8 & Able to relate previous knowledge in the conversation? & 6 & 14 & 14 & 6 \\
\hline
\end{tabular}

the pre-test. Overall, more students showed an increase of capability in their speaking skill in the post-test compared to the pre-test. Furthermore, the observed results before and after the implementation showed a positive improvement following the music-based intervention. By using the localized content such as the "Chan Mali Chan" tune with local song-based lyrics, students got into the context easier and even managed to introduce new ideas into the conversation. 14 pupils (70\%) are able to add in their previous knowledge about their friends during the discussion. Beside this, students showed improvement in their fluency and pronunciation.

\section{Research Question 2}

What are the significant differences in primary pupils' level of participation in English language classroom before and after the music-based intervention?

\section{Observation Checklist}

Table 6 shows the frequency scores of the observation that has been administered when the pupils are having discussion. The observed results before and after the implementation of music-based Intervention and improvise materials are showing no remarkable difference. The numbers of students who were not able to achieve the criteria in the speaking activities are almost similar in pre-test and post-test. Students' participation before and after the intervention in the discussion was remained.

Table 7 shows the frequency table of the observation from Observer $C$ that 
Table 6. Frequency distribution of the observation for Control Group.

\begin{tabular}{|c|c|c|c|c|c|}
\hline & \multirow{2}{*}{$\begin{array}{l}\text { In relation to the speaking activities } \\
\text { during the learning process. } \\
\text { Can the pupils }\end{array}$} & \multicolumn{2}{|c|}{ PRE } & \multicolumn{2}{|c|}{ POST } \\
\hline & & YES & NO & YES & $\mathrm{NO}$ \\
\hline 1 & Able to start a conversation? & 3 & 17 & 4 & 16 \\
\hline 4 & Keep a conversation going by using the wh-questions? & 7 & 13 & 6 & 13 \\
\hline 5 & Listen and respond to the speaker appropriately? & 5 & 15 & 5 & 15 \\
\hline 9 & Able to participate actively throughout the conversation? & 4 & 16 & 5 & 15 \\
\hline 10 & $\begin{array}{l}\text { Make eye contact and uses body gesture to express their } \\
\text { thought? }\end{array}$ & 9 & 11 & 12 & 8 \\
\hline
\end{tabular}

Table 7. Frequency distribution of the observation for Quasi-experimental group.

\begin{tabular}{llrrrrr}
\hline \multicolumn{1}{c}{$\begin{array}{c}\text { In relation to the speaking activities } \\
\text { during the learning process. } \\
\text { Can the pupils }\end{array}$} & PRE & \multicolumn{2}{c}{ POST } \\
\cline { 2 - 6 } & YES & NO & YES & NO \\
\hline $1 \quad$ able to start a conversation? & 4 & 16 & 9 & 11 \\
4 & $\begin{array}{l}\text { keep a conversation going by using the wh-questions? } \\
5\end{array}$ & 5 & 12 & 8 & 12 \\
\hline & $\begin{array}{l}\text { listen and respond to the speaker appropriately? } \\
\text { able to participate actively throughout the conversation? }\end{array}$ & 5 & 15 & 17 & 3 \\
10 & $\begin{array}{l}\text { make eye contact and uses body gesture to express their } \\
\text { thought? }\end{array}$ & 10 & 10 & 18 & 2 \\
\hline
\end{tabular}

has been administered when the pupils are having discussion. The observed results before and after the implementation of music-based Intervention and improvise materials have shown positive improvements as the students start to participate more in the discussion. As illustrated in Table 7, the numbers of students who can participate actively throughout the conversation in post-test increased by $60 \%$ which is tripled the number of students in pre-test. The results of this study illustrate that the inclusion of a music-based intervention and improvised materials in English class appears to have motivated the pupils to participate actively in the class discussion.

The findings of this study provide empirical evidence that the quasi-experimental group in which the music-based intervention and improvised materials was used was generally more successful and performed way better compared to the control group in terms of comprehension, vocabulary, grammar, fluency and pronunciation. In addition, it was found that there was significant difference between the quasi-experimental groups following music-based intervention with improvised materials and control group using the conventional learning with materials provided by Ministry of Education (MOE). The quasi-experimental group possesses higher mean score than the control group in their post-test performance respectively. It was proven that students who had gone through mu- 
sic-based intervention using improvised materials had showed improvement not only the content and vocabulary in the materials, but also their speaking skills especially their pronunciation and fluency.

Based on the observed results before and after the implementation of music-based Intervention and improvise materials have shown positive improvements as the students start to participate more in the discussion. Students who participated in this study also displayed a strong attraction towards the music-based activities as evidenced during the discussion, students start to participate actively. Music helps to create a fun and positive learning atmosphere in the classroom; it even benefitted the low performing students to overcome their fear and anxiety of learning English and increased their motivation to master a difficult language. Music had not only breaking the barrier of the students to learn, but also breaking the barrier between the students. According to Asrifan (2009), inserting songs in the lessons is one of the finest ways in creating a natural, anxiety-free environment. Singing activity makes the class dynamic and fun, and hold students' interest in the content that the teacher wished to deliver.

\section{Conclusion}

The main purpose of the study was to investigate how a music intervention which incorporated locally contextualized materials in teaching could be used to help increase English proficiency levels among low-performing pupils. In essence, the study found that pupils who had difficulty in mastering required levels of English proficiency as taught through regular school methods were able to improve in 6 lessons, using the researcher designed music intervention. Moreover, the music-based intervention helped to increase the low-performing pupils' motivation and interest to communicate in English, following the intervention as students showed an increase of capability in their speaking skill. Students' fluency had showed improvement too during the post-test. This finding is consistent with Kraus et al. (2014) on how music training helps to improve language and learning skills which lead to reading ability on English as researcher found that students showed more interest with music-based English class.

In light of Industrial Revolution 4.0 and soft skills such as communication skills that Malaysian school pupils will need to master to cater to growing industry needs, there is no doubt that the acquisition of English proficiency skills (both written and spoken) will be of utmost importance. A strong command of English will enable our younger generation to not only work, interact and communicate well within their chosen industries in Malaysia, it will also help Malaysian students to become more marketable and competitive in this globalized world. The English language is one of the most commonly used languages for communication, worldwide. Hence, innovative new solutions, such as the music-based intervention evaluated in this study will be needed to make sure that all Malaysian school pupils, including low performing pupils, can be equipped with English language skills as it will give them the advantage to engage with a 
wider range of knowledge in their chosen fields of work, and lead them to better job prospects in the future. Malaysian youth who are proficient in English will be more confident and have a wider access to job opportunities in the market.

\section{Conflicts of Interest}

The author declares no conflicts of interest regarding the publication of this paper.

\section{References}

Altenmüller, E., Leo, V., Särkämö, T., Sihvonen, A. J., \& Soinila, S. (2017). Music-Based Interventions in Neurological Rehabilitation. The Lancet Neurology, 16, 648-660. https://doi.org/10.1016/S1474-4422(17)30168-0

Anne, K. (2016). The Role of Music and Songs in Teaching English Vocabulary to Students. World Scientific News, 43, 1-55.

Asrifan, A. (2009). Using Songs in Teaching English Language for the Young Learners. Parepare: Universitas Muhammadiyah Parepare.

Azman, H., Lie, K. Y., \& Musa, N. C. (2012). Exploring English Language Learning and Teaching in Malaysia. Journal of Language Studies, 12, 35-51.

Bokiev, D., Bokiev, U., Aralas, D., Ismail, L., \& Othman, M. (2018). Utilizing Music and Songs to Promote Student Engagement in ESL Classrooms. International Journal of Academic Research in Business and Social Sciences, 8, 314-332.

Burns, D. S., Carpenter, J. S., \& Robb, S. L. (2010). Reporting Guidelines for Music-Based Interventions. Journal of Health Psychology, 16, 342-352.

https://doi.org/10.1177/1359105310374781

Degrave, P. (2019). Music in the Foreign Language Classroom: How and Why? Journal of Language Teaching and Research, 10, 412-420. https://doi.org/10.17507/jltr.1003.02

Gopalan, M., Rosinger, K., \& Ahn, J. B. (2020). Use of Quasi-Experimental Research Designs in Education Research: Growth, Promise, and Challenges. Review of Research in Education, 44, 218-243. https://doi.org/10.3102/0091732X20903302

Israel, H. F. (2013). Language Learning Enhanced by Music and Song. Literacy Information and Computer Education Journal (LICEJ), 2, 1360-1366.

https://doi.org/10.20533/licej.2040.2589.2013.0180

Kraus, N., O’Connell, S., Skoe, E., Slater, J., Strait, D. L., \& Thompson, E. (2014). Longitudinal Effects of Group Music Instruction on Literacy Skills in Low-Income Children. PLOS ONE, 9, e113383. https://doi.org/10.1371/journal.pone.0113383

Krishnan, P. D., \& Yunus, M. M. (2019). Blended CEFR in Enhancing Vocabulary among Low Proficiency Students. Arab World English Journal (AWEJ), 5, 141-153.

Matei, R., \& Ginsborg, J. (2017). Music Performance Anxiety in Classical Musicians-What We Know about What Works. BJPsych International, 14, 33-35. https://doi.org/10.1192/S2056474000001744

Ministry of Education Malaysia (MoE) (2018). Primary Curriculum Framework. Kuala Lumpur: Curriculum Development Centre.

Rosová, V. (2007). The Use of Music in Teaching English. Masaryk University.

Tegge, F. A. G. (2015). Investigating Song-Based Language Teaching and Its Effect on Lexical Learning. Doctoral Dissertation, Victoria University of Wellington.

Tse, A. Y. H. (2015). Malaysian Teachers' Perspectives on Using Songs in English Language Teaching. International Journal of Social Science and Humanity, 5, 87-89. https://doi.org/10.7763/IJSSH.2015.V5.428 